\title{
Guillermo del Toro's The Shape of Water (2017): Trump Era Update of Cold War Creature from the Black Lagoon (1954) and Civil War Reckoning El laberinto del fauno (2006).
}

Elizabeth Jane Garrels

Massachusets Institute of Technology

egarrels@mit.edu

\begin{abstract}
Guillermo Del Toro's latest film uses an amphibian creature dragged from the Amazon to reflect on the current situation of immigrants in this country, especially those from south of the border. In the process, the director uses Trump's nationalist and racist framing of the immigration debate as an opportunity to remake a film he has loved since childhood, "Creature From the Black Lagoon." He places his film in 1962, during the Cuban Missile Crisis, but he insists that he has made a film that, although it takes place in the past, talks about the present. He also reworks a number of the themes
\end{abstract}


and characterizations from his 2006 Spanish-language film "El laberinto del fauno." Both films, one situated in Franco's Spain shortly after the Civil War, and the other, in J.F.K.'s Camelot, nonetheless present equally chilling visions of systems of political power that foster brutal, authoritarian, and unforgiving social behaviors.

Keywords: Guillermo del Toro; film; immigration; Cold War; Trump

\section{Resumen}

La última película de Guillermo del Toro utiliza una criatura anfibia arrastrada desde el Amazonas para reflexionar sobre la situación actual de los inmigrantes en Estados Unidos, especialmente los que vienen desde el sur de la frontera. En el proceso, el director utiliza los referentes nacionalistas y racistas con los que Trump ha enmarcado el debate sobre la inmigración para rehacer una película que él ha admirado desde la infancia: "Creature From the Black Lagoon". Del Toro sitúa su película en 1962, durante la crisis de los misiles en Cuba, pero insiste en que ha hecho una película que, aunque tiene lugar en el pasado, habla sobre el presente. Al mismo tiempo, reelabora algunos de los temas y caracterizaciones de su película en español "El laberinto del fauno" de 2006. Ambas películas, una situada en la España de Franco poco después de la Guerra Civil, y la otra en el Camelot de J.F.K., presentan, no obstante, visiones igualmente escalofriantes de sistemas de poder político que fomentan conductas sociales autoritarias, implacables, y brutales.

Palabras clave: Guillermo del Toro; cine; immigración; Guerra fría; Trump 
$\mathbf{T}$ his essay is a somewhat developed version of a brief presentation made to an academic audience in April of 2018. At that time, I wished to communicate my early reactions to a film I had initially seen just months before in December of the previous year. Having survived the first year of the Trump presidency, I experienced del Toro's film as a much-needed injection of frontal attack through popular film. I was gratified to read that in three different cinemas where it had played in Arizona, largely conservative white audiences had been captivated.' I myself had seen people stand and applaud at the Capitol Theatre in Arlington, Mass. Now, a year later, and after one more Oscar to a Mexican director, the film deserves a different kind of reading. Over the year, however, the critical literature on del Toro's film has grown very little; perhaps my early and very personal reaction will, with a few minor updates included here, serve to jump-start the discussion.

In my title, I promise to discuss Guillermo del Toro's Oscar-winning film The Shape of Water (2017) as a Trump era update of two earlier films. One, a Hollywood B-movie, was made and situated during the Cold War. The other, a much more recent, and international production directed in Spanish by del Toro himself, is situated in Franco's Spain in 1944, in the nasty aftermath of that country's tragic civil war. My choice of these two films in particular merits an explanation, especially since The Shape of Water uses homages and clips from numerous films and U.S. television shows as the very building blocks for its own construction. It is a film about the pleasures of watching the luminous screen. But it is also a film about intolerance and political violence.

Since the release of his Oscar-winning film, del Toro has insisted in his frequent interviews with the press that the current moment in U.S. politics is charged with violence, and that Trump's slogan to "Make America Great Again" holds up the early 60s as a mythic past when America was indeed great and to which we should strive to return. Del Toro uses his film to debunk this myth. He shows the violence beneath the surface (i.e. in top secret government 
laboratories) and in plain view on Southern streets and television screens nationwide that in fact constituted the reality of the early 1960 s, even prior to Kennedy's assassination in the fall of 1963. The theme of violence, embodied in the character Richard Strickland and the terrifying threat of General Hoyt to convert Strickland into a non-person should he fail to find the missing "asset," posits violence at a level consistent with its extreme fascistic embodiment in the character of Capitán Vidal (Sergi López) in del Toro's 2006 Laberinto del fauno. The takeaway here is that, since at least the early 60s, the U.S. has tolerated and even fostered brutal fascistic behaviors in its public servants that public myth in the U.S. might have acknowledged in Franco's early regime (before Eisenhower's visit) but never would have conceded as possible in the democratic United States. Thus, political violence, indeed sadism, thematically ties these two films by del Toro together, in addition to strong stylistic and narrative similarities that I will discuss later.

As for my choice of Creature from the Black Lagoon (1954), I must confess to strong personal reasons that somewhat coincide with del Toro's admitted childhood fascination with this film. Creature was released in Silver Spring, Md., near where I was living, when I was eight years old. Like the child del Toro, I went to the movies as often as I could get adults to take me, and I watched as much TV as I could get away with. I saw the previews (trailers) of Creature at the Apex Cinema and was aghast. Having seen a Sabú episode on Andy's Gang in which a character's young and attractive mother was killed, while swimming, by a giant squid who came for her with its/his tentacles from below, I related the underwater scene of the Creature tracking Julie Adams from below with the deadly encounter between giant squid and young woman from India.' After that, only the apparent safety of Esther William's swimming pools gave me a sensual aquatic environment where I could feel safe. I purposely never saw Creature from the Black Lagoon until December of 2017, in preparation for del Toro's Shape, advertised as a loose and friendly remake of Creature. At age 
71, I loved Jack Arnold's film, but even now could not identify with del Toro's childhood fantasy that the Creature should end up with the girl. For me, it was still a film about the predation of women. Nonetheless, my long-delayed discovery of Creature in its entirety, coupled with my profound respect for del Toro's portrayal in Laberinto of Spanish fascism and Franco's military inebriated with its recent victory determined my choice of these two films for my analysis of The Shape of Water.

On March 4, 2018, at the Oscar ceremony in Los Angeles, Mexican Guillermo del Toro began his acceptance speech for Best Director with these words, "I am an immigrant." Later, that same evening, del Toro went on to accept the prize for best film, for his English-language "creature feature" The Shape of Water. The Mexican immigrant, who chose to flee the violence of his native country after his wealthy father was kidnapped for ransom in 1998, has no illusions about the peace and tranquility of his new residence north of the border, where he lives outside of Los Angeles, when he isn't travelling or living in Toronto.

His Oscar-winning film, though largely shot in Toronto, takes place in Baltimore, Md., in the autumn of 1962. Del Toro has taken great pains in his reconstruction of the historical moment, although his film is not without anachronisms. Several of these led a handful of early commentators to place the film's action in 1963. For example, one of the more useful commentaries in this group, titled "Goofs from The Shape of Water," states, "The wall calendar Eliza [sic] uses is from the fall of 1962, yet the newsreels shown on television and the narrator's reference to 'the last days of a fair Prince's reign' make it clear it is early May 1963." The prince, of course, is the handsome young president from Camelot, John F. Kennedy, who will be assassinated on November 22, 1963; the newsreels are of police with fire hoses and dogs attacking young black Americans in Birmingham, Al., on May 3, 1963. Yet the proximity of Kennedy's assassination or the anachronistic use of newsreels depicting the extremes to 
which Birmingham's white establishment was willing to go to preserve racial segregation do not warrant placing the film's action that far ahead. Eliza's wall calendar, which gives us the exact date of the Creature's return to nature and, indeed, of the climax and denouement of the entire film, is undeniably specific: October 10, 1962.

This movie is fantasy, with strong political implications, and its director, who also co-authored the screenplay, has allowed himself historical license for a number of reasons, among them, to highlight the background of racial tension and violence that whites Elisa Esposito (Sally Hawkins) and Giles (Richard Jenkins), living in Baltimore, a city nearly as densely black as Birmingham, seem bent on ignoring. The narrative and historical weight of October 10, 1962, however, is not only compelling because it marks the goal toward which Elisa and her recent co-conspirators Giles and Zelda (Octavia Spencer) are working. In the history outside the film, this date is a mere six days before the beginning of the Cuban Missile Crisis. The action of the film ends less than a week before the onset of the thirteen-day confrontation between the U.S., on one hand, and Russia and Cuba, on the other, that is widely considered to have brought the world to the brink of nuclear war. The film compresses these dates. For one, it has President Kennedy delivering his October 22 radio and TV "Report to the American People on the Soviet Arms Buildup in Cuba" more than a week before October 10. As Giles is trying to get past security at the top-secret military facility to rush the liberated Creature off to Elisa's apartment, the audience, with luck, may recognize fairly inaudible snippets of Kennedy's distinctive voice emanating from the radio in the guard booth. It is this October 22 speech that the nation's president is delivering, but the film's quasi-fictional chronology puts the broadcast sometime in late September. ${ }^{2}$

By tweaking history, del Toro has placed his romance of a 1960s Cinderella and a beautiful male water god at the dead center of a real-life brush with annihilation for the human race. However, the film purposely creates this 
super-charged historical backdrop only to proceed to distract the viewer's attention away from it. Certainly, with the exception of the Russian scientist/ spy Hoffstetler (Michael Stuhlbarg), the heroes and supporting heroes of this romance are hardly aware of it at all. They play out their intense drama of bravery and life-defining acts and decisions on the level of the strictly personal. On the other hand, we know that the brass at the top-secret military facility are aware that the Russians have placed missiles in Cuba, but just as the film purposely underplays the radio broadcast of Kennedy's speech, the other concrete reference it makes to Cuban missiles occurs offhandedly during a jocular exchange between the two major villains of the film, security officer Richard Strickland (Michael Shannon) and the avuncular but steely General Hoyt (Nick Searcy). This time, the horrifically destabilizing missiles have to compete for the audience's attention with a subjective shift of the film's sound track as it momentarily reproduces what a very frightened Dr. Hoffstetler is able to hear when he suddenly makes two alarming discoveries, one after another.

Beginning at 42:38 minutes into the film, General Hoyt addresses Strickland and Hoffstetler about the Creature:

Well, the Soviets want it. We know that much. Those cockeyed bastards. You know, we let'em send a dog up into space, and we get a good laugh. And then the next thing you know, they send a human up, a Ruskie, orbiting the planet, doing God knows what. And who's laughing then? Kruschev. That's who. We let him put a dog in space, and he laughs, then he puts a commie up in space, and he laughs, and then he puts missiles into Cuba. Have we learned nothing?

About half way through this speech, Hoffstetler sees that Elisa is hiding in the room; he is immediately startled and nervous that she will be discovered. At this point, the content of General Hoyt's speech becomes distorted and blurred for the audience as the sound track identifies with Hoffstetler's 
momentary panic. However, by the time Hoyt gets to the end of speech, Hoffstetler has composed himself and turned his attention to the Creature who has now spent too much time out of water and is in grave danger. The sound distortion has consequently disappeared, and the viewer clearly hears General Hoyt conclude with the words, "and then he puts missiles into Cuba. Have we learned nothing?"

The top-secret military facility where the Creature is imprisoned and tortured between September 17, 1962, and his liberation sometime before October 3, is a U.S. Aerospace Research Center, whose mission is to assure that the U.S. outperforms its Russian competitors in outer space. In this sense, del Toro's film is a Cold War spy thriller, complete with Russian agents who plant a spy in the facility (Hoffstetler) and who speak Russian with each other, while most of us in the audience read sub-titles. Richard Strickland has been sent to South America to bring back an amphibious creature from the Amazon, whose dual respiratory mechanism might offer clues on how human astronauts could survive beyond earth's atmosphere. The Creature, called the "asset" by the lab's technicians, has been taken from a muddy river where the natives worship him as a god. This is all we know of his origin.

But the same night that Strickland arrives with the Creature at the Research Center in Baltimore, Elisa goes out onto the street to catch a bus to her job on the graveyard shift as a cleaning woman at the same Center. Once she is outside, we see fire engines hurry by and at the end of the street, a building hurling enormous flames up into the darkened sky. Elisa's neighbor Giles has already told her that the local chocolate factory is on fire and that the air smells of "toasted cocoa, tragedy and delight, hand in hand" (The Shape of Water 05:45mins.). I have seen no references to this factory fire in discussions of the film, but nothing in this film is accidental, so what could it mean? The fire and the smell of burnt chocolate mark the beginning of the story, the night the Creature arrives at the facility and the night Elisa first sets eyes on 
him. This night, something is amiss in the world, but there is also the promise of delight. Giles speaks of tragedy and delight together, and his paradoxical judgment of the immediate situation will also serve, if remembered at the end of the film, to describe the history and outcome of Elisa's romance with the Creature. His delight at the smell of burnt chocolate should come as no surprise; indeed, chocolate has been valued for centuries and almost universally considered a source of pleasure. Cacao, the plant from which chocolate is made, is, like the divine amphibian trapped in a tank, another New World original. In Mesoamerica, cacao was cultivated and used to make liquid chocolate centuries before the Spaniards arrived. The Mayans and the Aztecs considered cacao sacred, a gift from the gods, to whom, in turn, they gave ritual offerings of cacao during religious observations (Dillinger). The film provides an inaugural backdrop of destructive bursts of flame and the smell of burnt chocolate: are Mesoamerican gods showing their anger at Strickland's progress-driven desecration of a natural order that clearly accommodates more incarnations of the divine than he can even begin to imagine?

The Creature arrives on September 17 in a cramped tank and will be released, for observation, into a somewhat larger one at the facility. Like the film's director Guillermo del Toro, the Creature is an immigrant from south of the border. Unlike del Toro, however, he did not flee from violence in his own land. Shown to us in numerous scenes chained and bloodied from torture, he belongs to the New World's history of forced migration, the most notable example of which were the roughly ten million enslaved Africans transported across the Atlantic to work, against their will, in the homes and fields of their white owners. Over time, the forced migrants and their descendants have suffered, along with many of the United States' voluntary immigrants, from the dominant white culture's practices of othering, replete with strategies of dehumanization: they can't speak English, so basically, they can't speak; they look different, so they must be animals, etc. Del Toro accounts for all this in 
his film, and in the second half of 2016, when the film was shot, ${ }^{4}$ he was well aware of candidate Trump's generalization that "The Mexican Government is forcing their most unwanted people into the United States. They are, in many cases, criminals, drug dealers, rapists, etc." (Walker).

In numerous interviews, del Toro has admitted that with Shape, he wished to make a film situated in the past that would also speak to the present. In September, 2017, after the film had screened at a few festivals, but before it was released in the United States, Vanity Fair asked del Toro, "Why did you set this during the Cold War?" To which the director answered:

...when America talks about "Make America Great Again," it's talking about 1962, the end of Camelot, the peak of the promise of the future, jet-fin cars, super-fast kitchens, television, everything that if you're white, Anglo-Saxon, heterosexual, you're good. But if you're anything else, you're not so good. Then when Kennedy is shot and Vietnam escalates, and the disillusionment of that dream occurs, I don't think that has healed. We're living in a time where the one percent has created a narrative in which they are not to blame. Who is to blame is them, quote unquote, the others, Mexicans, the minorities. What the creation of that other does, it exonerates from responsibility. It directs hatred in a super streamlined way. (Keegan)

On February 10, 2018, when del Toro was in Spain for the very belated opening of the film in that country, he said the following to a reporter of El Pais:

La intolerancia, la rabia, el miedo, la xenofobia actual nace de ese presidente que pregona el 'Hagamos América grande' al estilo de la Guerra Fría, época en la que se desarrolla la película como reflejo del presente. Es muy bonito encapsular la otredad en una criatura y poder jugar con que sea un dios... o un bicho repugnante que procede de Sudamérica, como cree el antagonista... La ideología tiende a separarnos y en realidad somos uno. Matando a la otredad no acabas con el problema, por mucho que así lo diga Trump. (Belinchón) 
Del Toro's bicho repugnante, whom the film's sadistic antagonist Strickland finally acknowledges to be a god, takes us directly to one of the work's most obvious precursors, the 1954 U.S. horror flick from Universal-International directed by Jack Arnold, Creature from the Black Lagoon. The action there takes place in the Brazilian Amazon; indeed, at one point we see the Brazilian flag flying over a local scientific research center. Del Toro's much less aggressive Creature is from a far more generic or less nationally specific South America. Strickland tells us he took him from "the river muck in South America" (Shape 28:39 mins.), and the only time he mentions the Amazon is in reference to the natives who worship the creature and who "Tried to stop the oil drill with bows and arrows" (Shape 41:12 mins). Is this reference to an oil drill yet another of the film's anachronisms?

Oil exploration in the Amazon only began in earnest in the early 1960s, and the places where there has been the greatest oil extraction, with the resultant ecological damage and displacement and poisoning of local indigenous people, are in Ecuador and Peru. In contrast, the Brazilian Amazon has seen relatively modest oil and gas development, although interest in new exploitation has increased in the last twenty years. Brazil's considerable oil wealth, of recent date, does not come from the Amazon, but from offshore drilling in the Atlantic Ocean. ${ }^{5}$

In reality, the Amazon river and rain forest exist in a number of South America's countries, and Strickland's vagueness about the creature's geographical origin and the curious reference to the oil drill suggest a more generic Amazonian filiation. No one country can claim this creature as its own. Thus, the anti-immigrant, white-supremacist discourse that indiscriminately lumps together those who move northward across the U.S. border (a content latent in all of Strickland's attacks against the Creature) finds in this new and more sophisticated version of Jack Arnold's Gill-man a more transnational object. Del Toro's film obviously takes the Creature's side, and uses his situation 
to generalize about the plight of Latino immigrants in this country. However, we should note that in spite of the film's pro-immigrant stance, its only identifiable Latino (Elisa's name is not conclusive proof of Hispanic descent) is the minor but mean-spirited character Yolanda, who complains about Elisa arriving late and who repeatedly calls her "dummy." Yolanda provides the film with a self-critical moment of recognition that both inside and outside of del Toro's fictional world, sisterhood and working-class solidarity are hardly universal, nor are all Latino immigrants nice people.

Thus, if the film's attention to Carmen Miranda's "Chica Chica Boom Chic," which she first performed in the 1941 Hollywood film That Night in Rio, draws our imagination back to the Brazilian jungle of the 1954 Creature from the Black Lagoon, we need also to pay attention to the only other Latin American song in The Shape of Water's carefully assembled soundtrack. This is "Babalú," written by the Cuban Margarita Lecuona and performed by the multi-lingual Italian singer Caterina Valente, who in the 1950s and 1960s helped popularize Spanish-language standards in the U.S. and abroad. With the musical presence of "Babalú" in del Toro's film, yet another Latin American deity, Babalú-Ayé, the Afro-Cuban or Santería equivalent of Saint Lazarus, insinuates itself into this narrative universe, chipping away at Richard Strickland's already feeble authority when he states that god looks like him, a white male. Finally, "Babalú" reminds us that in 1962, Cuba was much on the mind here in the United States.

In Creature from the Black Lagoon, the Julie Adams character, though primarily a female sex object competed for by male amphibian creature and male humans, is also an employed scientist, who, according to one of her male colleagues, has done "valuable research" (Creature 46:43 mins.). (Regardless of how good a scientist she is, though, she is never referred to in the film as "Doctor," and perhaps she doesn't hold that advanced degree; her male colleagues, on the other hand, repeatedly call each other by that title.) In 
the U.S., in 1962, it would appear that a mute orphan, although white and brought up in a Catholic orphanage to have very middle-class manners and taste in clothing, can only, because of her disability, get the kind of work that the local blacks get, that is, in Strickland's words, as "shit cleaners," and "piss wipers" (Shape 1:15:32 mins.). Clearly, if she were not mute, she would probably have to settle for, at best, something like Strickland's secretary. Despite Julie Adams's fictional persona from 1954, in 1962, becoming a scientist would have been a stretch for any woman. But we should not doubt Elisa's possible talent for such work. She is intelligent and observant; the Russian spy and scientist Dr. Hoffstetler expresses admiration for her savvy in planning the Creature's escape. Denied many of the opportunities and tools of learning, she continues to observe and learn even in her relatively limited universe. Knowing that the director was Mexican and seeing Elisa masturbate in the bathtub to the discipline of an egg timer, I could not help but think of Sor Juana's famous words about what she learned while watching eggs as they cook, "Pues ¿qué os pudiera contar, Señora, de los secretos que he descubierto estando guisando?... ¿qué podemos saber las mujeres sino filosofías de cocina” ("Respuesta” 838). ${ }^{6}$ Furthermore, Elisa may be mute, but she is not speechless. She signs American Sign Language, and she teaches Giles, Zelda, and eventually the Creature to communicate in her language.? These "losers," in Strickland's (and Trump's) opinion, are infinitely better students and learners than either of these men. Elisa is a teacher, and she also comes to see that she can defy and outwit oppressive authority in the name of friendship and decency. This is perhaps the greatest leap forward in her education as a competent and principled adult.

The character of Elisa as "the princess without voice" (Shape 02:30 mins.) of del Toro's fairy tale plot is complicated by the film's multi-generic identifications. The director has made it clear in numerous interviews that The Shape of Water is the remake of Jack Arnold's 1954 monster movie that he had been yearning to film ever since he first saw it, on T.V., at the age of six or 
seven. Apparently, the young boy had identified with the aquatic creature, and his reaction to the film was both romantic and erotic:

When I saw the creature swimming under Julie Adams, I thought three things: I thought, "Hubba-hubba." I thought, "This is the most poetic thing I'll ever see." I was overwhelmed by the beauty. And the third thing I thought is, "I hope they end up together." (Rottenberg) ${ }^{8}$

Indeed, in The Shape, the Creature does get the girl; in fact, it could be argued that he also gets his own way. If he is divine and can miraculously cure not only his own wounds but those of humans, why doesn't he bring Elisa back to life as a human? It is clear that the Creature does not want to live in Elisa's world; it isn't healthy for him, and he isn't free. His misery sitting at Elisa's kitchen table peeling his eggs is not unlike Strickland's zombie-like state at home in front of the television; arguably, both men are feeling suffocated by domesticity. Instead of bringing Elisa back to life in the human world, where she would have to stand trial, along with Giles and Zelda, for their roles in the theft of the pentagon's "asset," and where she and the Creature would be separated, star-crossed lovers, the Creature chooses to revive her as an amphibian. This way the two of them can resolve their respective loneliness and love each other far from the reach of an oppressive human state. However, once the Creature makes this decision on his own, the relationship of these two soul mates tilts definitely in his favor. The Creature is a god, and Elisa is a mere human being. ${ }^{9}$ The god is the one who is able to make the ultimate life and death decision for both of them. Not Elisa, for she is dead when the Creature makes the decision concerning her species form and her future.

Up until the end of the film when both of them get shot "to death" by Strickland, Elisa is the active one in the relationship. The Creature is passive and childlike. Elisa teaches him (sign) language, how to sit at the kitchen table to eat his eggs, and even how to peel them properly with his amphibian claws. 
It is she who initiates their love making. In her world, she, as a competent human being, is in control. One can question whether their relationship up to this point has been one of equals, or one more like that of teacher and pupil. When she rescues him from certain death at the research center, she is certainly the "hero," the "knight," the Paper Bag Princess of Robert Munsch's 1980 feminist fairy tale. Once the two lovers are in the river's waters at the film's conclusion, however, they are in his world, and he is in control. There has been a clear reversal of roles. We should ask, will theirs be a relationship of equals? Will Elisa have to learn how to be an amphibian, or will it come naturally? Will she ever achieve the status of a divinity, or will she remain in some more lowly amphibian state? All this is conjecture. As the film ends, each, in turn, has successfully saved the other from extinction. Perhaps this makes them equal. A fact that we do observe is that in the water, after the Creature has laid his healing hand on Elisa's neck and while he is kissing her, Elisa loses one of her red shoes, one of her mythical (à la Dorothy of "Oz") red slippers or dancing shoes. Presumably, Elisa will never dance again, and this is a loss. But losing, or kicking off, a shoe is also a classical Hollywood cliché with clear sexual connotations. Under the Hays Code, an erotic scene about to become more sexual often closed with one or both of the lovers dropping a shoe, which was to be understood as the beginning of the strip that the audience was not allowed to see. The woman lost her shoe as she surrendered to love. Could this be code in del Toro's film for a final marriage vow of "I do"? As soon as the kiss is completed and the shoe is gone, Elisa springs her new set of gills and begins to breath under water. She smiles and embraces her mate.

Adult love and sensuality are two themes that del Toro points to when journalists challenge him to distinguish between Shape and his earlier films El espinazo del diablo (2001) and El laberinto del fauno (2006). Indeed, some critics suggest that these three films form a triptych or trilogy because of their protagonism of innocent and vulnerable children (or, in the case of Shape, a 
childlike adult), their fairy-tale, haunted, or fantastic universes, which provide each film with at least one other-worldly character, and their casting of the villain as an adult male who embodies a terrifyingly violent and authoritarian political regime that exists in the "real" world and not in the make-believe one..$^{10}$ To these similarities, one could add others: all three are framed narratives (In Shape, Giles provides the voice-over both at the beginning and at the end of the film), and all three choose protagonists who are orphans. But del Toro insists that, unlike the other two films, Shape deals with his most pressing personal concerns in the present:

Most of the time-in "Pan's Labyrinth" or "Devil's Backbone"-l'm talking about my childhood. Here, I'm talking about me with adult concerns. Cinema. Love. The idea of otherness being seen as the enemy. What I feel as an immigrant. What I feel is an ugly undercurrent not in the past-not in the origins of fascism-but now. It is a movie that talks about the present for me. Even if it's set in 1962, it talks about me now. (Rottenberg)

In his interview with Beatriz Martínez for El País, del Toro stresses the theme of love as that which makes this film "más maduro" than the other two: "Quería adentrarme en las necesidades de los adultos, en sus pulsiones internas, pero desde un punto de vista muy vitalista. Por eso la película está cargada de amor: de amor a la vida, de amor al cine, de amor al amor."

Of the two Spanish-language films to which Shape has been compared, the more obvious precursor is the 2006 Laberinto, and this is, in good part, due to their respective heroines. ${ }^{11}$ In many ways, Elisa is the filmic successor to Ofelia (Ivana Baquero), the female child heroine of Laberinto who is murdered by the fascist villain Capitán Vidal when she is only ten years old, and thus, is never allowed to reach adulthood. At the time of her death, Ofelia is an orphan, for she has lost both her mother and father, and remains in the power of her murderous stepfather, Capitán Vidal. Elisa, on the other hand, never 


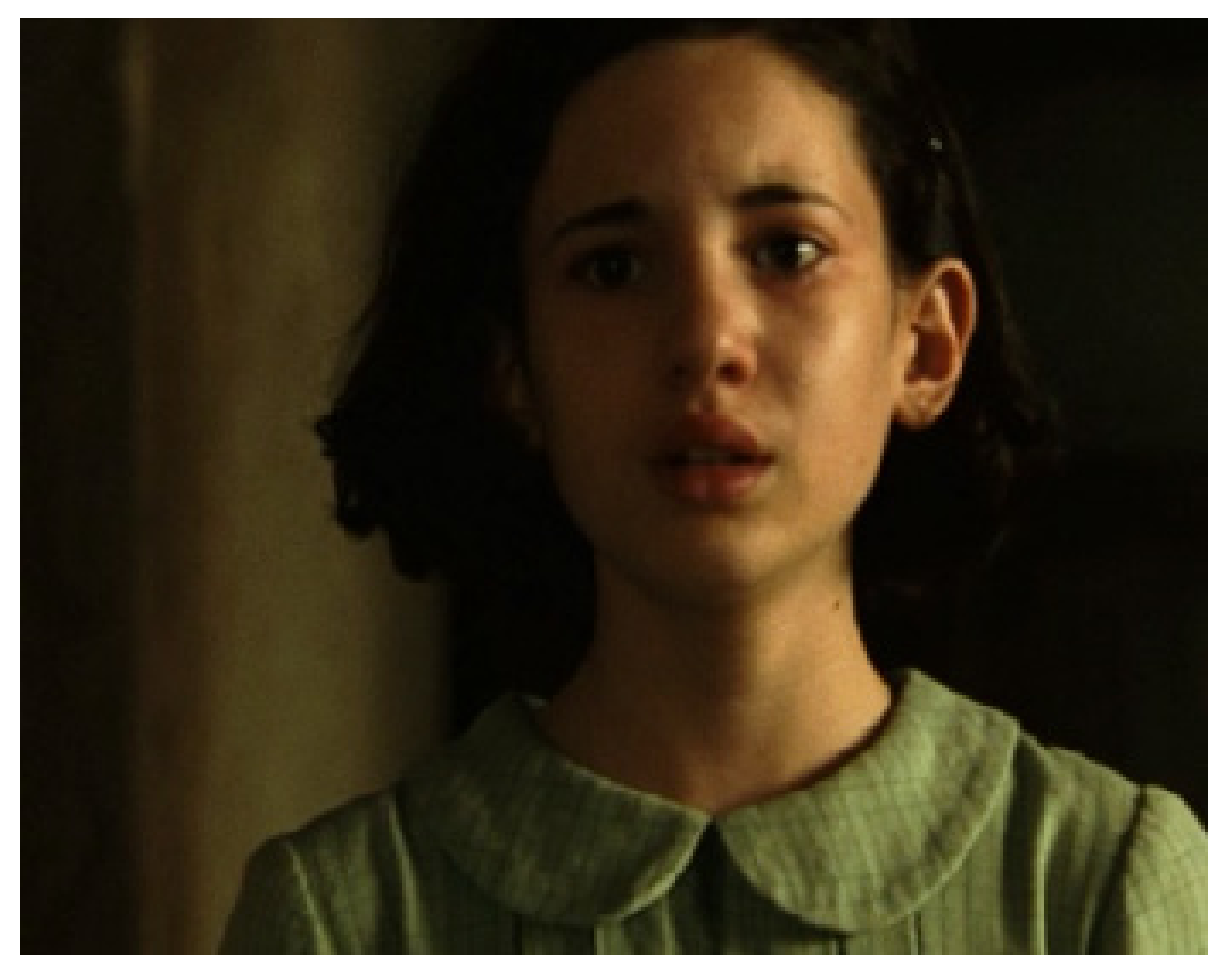

Ten-year old Ofelia with round collar blouse (Laberinto, 1:25:48).

knew her parents, as an infant she was physically abused and rendered mute, and she grew up in an orphanage. She now lives alone, and holds down a job. She has successfully reached adulthood, and has adult feelings and sexual needs. However, in spite of her age and adult sexuality, there is much in her appearance and manners that is childlike. Physically, Elisa looks and dresses like an adult Ofelia. Both are brunette and have the same hairdo (Elisa's is a little longer), both wear round collar blouses, and both have a love for red shoes.

The adult Elisa not only looks girlish, but frequently acts the ingénue, as when she brings home the very campy and childish greeting card for her friend 


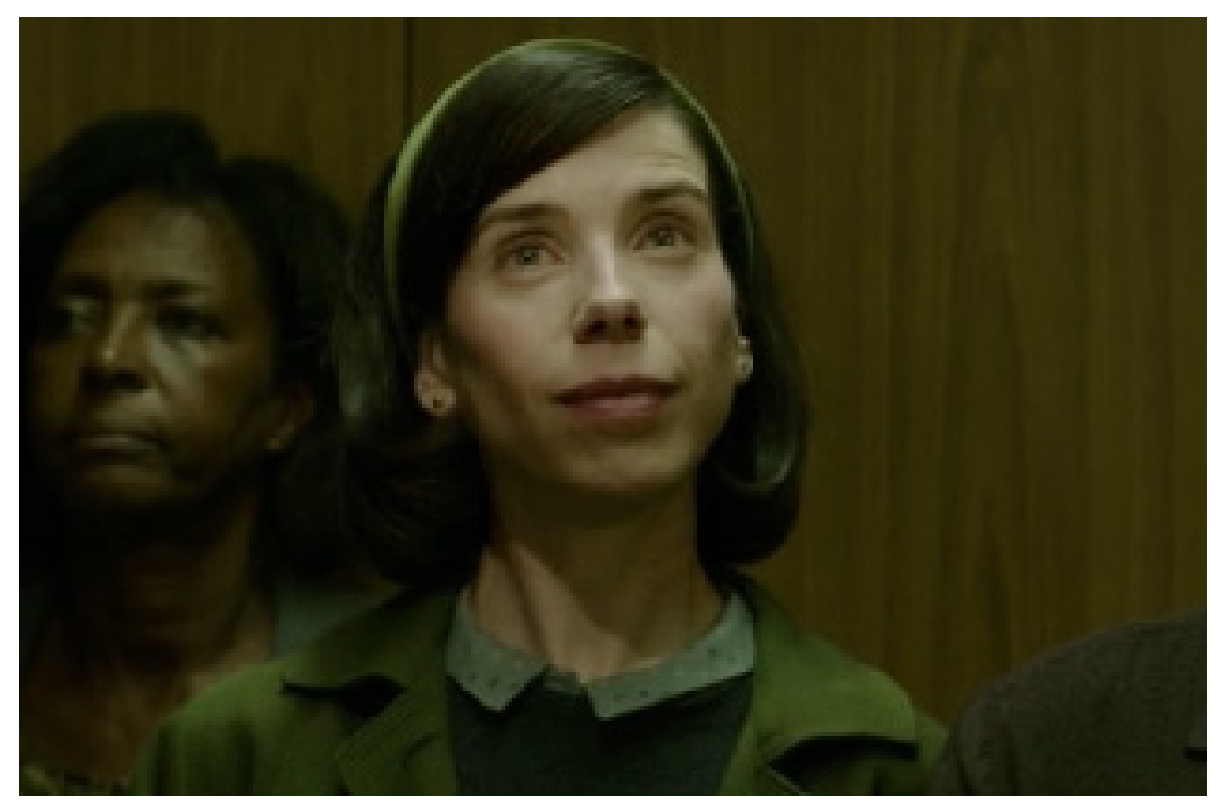

The adult Elisa with round collar blouse and girlish hairdo (Shape 1:11:59).

in the bath tub because it shows a fish in a fishbowl and, on a literal but unintended level, promotes friendship between different species. Both Ofelia and Elisa share a similar tragic trajectory. Both heroically defy a dehumanizing system and the incarnation of that system in a sadistic male authority figure. Both are ultimately killed by the villain, in what are gratuitous, professionally unnecessary, and, in fact, personal revenge crimes. Indeed, both dead bodies are filmed in similar fashion by del Toro's camera. Most striking of all, both heroines, as rewards for their goodness, are resurrected after death to live in a better, happier, more loving, and more just world, beyond the limitations and sufferings of the human one.12

Elisa's character actually condenses features of two of the female protagonists of El laberinto del fauno. Not only is Elisa a grownup Ofelia, 


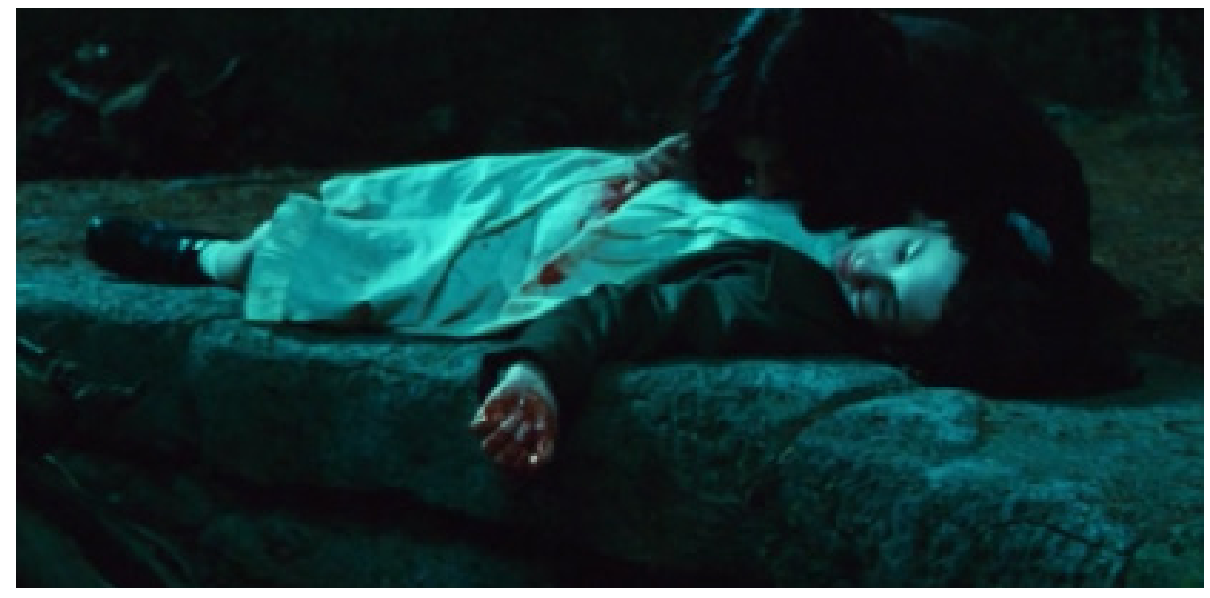

Ofelia dead after being fatally shot by Capitán Vidal (Laberinto 1:51:38).

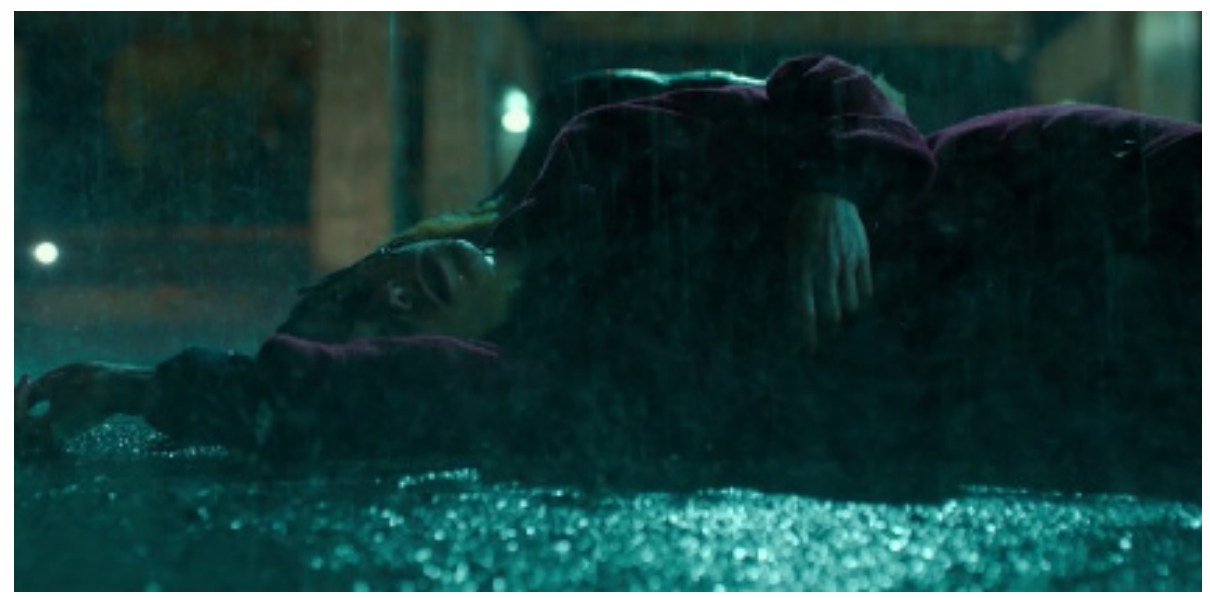

Elisa dead after being fatally shot by Richard Strickland (Shape 1:53:44). 
but as an invisible (and "speechless"), but also subversive cleaning lady, she reproduces qualities of Mercedes (Maribel Verdú), Capitán Vidal's workingclass housekeeper. Both women actively resist injustice for a higher good, and for both of them, avoiding the sexual insinuations and overtures of their male bosses is, unfortunately, part of their job.

It may seem ironic that del Toro should create similar narratives for 1944 in Spain and 1962 in the United States. In 1944, Franco was intent on eliminating surviving members of the Republican army and many of the progressives who had defied him. El laberinto del fauno places the fairytale world of justice and peace, "donde no existe la mentira ni el dolor" (Laberinto 01:48 mins.), in an underground realm, very different from the human world. In contrast, the presidency of John F. Kennedy created its own fairytale mythology, Camelot, which suggested that happiness and fulfillment could be found in the present, and immediate future, in the United States. Del Toro, who throughout his life has repeatedly been stopped and questioned at the border, debunks that myth. It only included middle and upper-class whites from the U.S., and clearly favored the males. ${ }^{13}$ Del Toro insists on reminding us that while U.S. power was creating its own self-congratulatory narrative, the Bay of Pigs invasion, the Cuban Missile Crisis, the Vietnam War, and the violent responses to the Civil Rights Movement forced recognition of another, crueler reality on U.S. and international audiences. Today, the unresolved inequities and injustices in the United States have unleashed a grotesque return of the repressed, in real-life figures like Steve Bannon, allied with the extreme right of the Spanish Catholic Church and the nationalist party Vox, in Donald Trump, puppet for many of the Right Wing's darkest causes, and in Mitch McConnell and Jefferson Beauregard Sessions III (deemed expendable as of this rewriting), both deeply committed to enacting the Republican Party's Southern Strategy and to putting women, sexual minorities, and people of color in the unenviable subordinate places they have chosen for them. 


\section{Notes}

1 Kim Nicolini, "Surf N Turf: Love and Acceptance in Guillermo del Toro's The Shape of Water." www.counterpunch.org, Jan. 5, 2018.

2 https://www.imdb.com/title/tt0047712/

3 I owe my awareness of the content of the radio broadcast, which is extremely difficult for the film's viewer to capture, to the IMDb website "The Shape of Water (2017): Goofs." The action of the film begins on the day Elisa and the Creature meet, and we know this is Monday, September 17, because this is the date on the sheet of paper that Elisa tears off her kitchen calendar before she leaves for work that day. Thus, the film covers a period of twenty-four days. During this time, the audience gets two additional chances to see a date on Elisa's calendar. The second will be the date of the Creature's release into the river, on October 10, 1962. The first, more difficult to notice, will be the date of Wednesday, October 3 , which will appear in the kitchen scene where Elisa and Giles unpack groceries. This occurs on the day Elisa has visited the river to check on the water level and then returned home with groceries and a greeting card for her guest. The guest, of course, is the Creature, and he has already been sprung from the research facility and has now taken up residence in Elisa's bathtub. This particular calendar reading allows us to calculate that the Creature was liberated from his military captors sometime before October 3, possibly at the end of September. Whatever that date may have been, it is the same one on which President Kennedy delivers his October 22 speech within the film.

4 Filming began on August 15, 2016, in Toronto, and ended twelve weeks later ("Guillermo del Toro").

5 Sources consulted on oil exploitation in the Amazon include Sample, Butler, Miller, Brooke, and Finer. In 2008, Finer, et al. wrote, "Oil and gas projects affect the forest of all western Amazonian nations, but to varying degrees. For example, in both Ecuador and Peru blocks now cover more than two-thirds of the Amazon, while in Colombia that fraction is less than one-tenth. In Bolivia and western Brazil, historical impacts are minimal, but the area open to oil and gas exploration is increasing rapidly". (2) For the record, it should be noted that an oil refinery has been operating in Manaus, the capital of the Brazilian state of Amazonas, since 1956-57.

6 The context for Sor Juana's observation about eggs, found in her "Respuesta a Sor Filotea," is the time spent in her convent's kitchen when she was prohibited by her confessor from reading her books. Without her books and her scientific instruments, the intellectual and ever-curious Mexican nun had to study her 
more mundane surroundings. The comparison of Elisa to Sor Juana is instructive. We do not know if Elisa is a reader, although it is clear that her neighbor and close friend Giles is. In any case, she has learned how to be an excellent reader of her surroundings. Director del Toro already revealed his familiarity with Sor Juana's writing in an earlier film, El espinazo del diablo (2001). In that film, Dr. Casares recites one of Sor Juana's many romances to Carmen, the director of the orphanage where the action takes place. The romance of the film figures in the Porrúa edition of Obras completas de Sor Juana Inés de la Cruz in the section "Romances filosóficos y amorosos (sin fechas conjeturables)." It is the second of the "Tres 'Letras para cantar'," and its first verse is "Afuera, afuera, ansias mías."

7 Within the disability debate surrounding this film, Sally Hawkins, who plays Elisa, has been criticized for "her poor skills in American Sign Language (ASL)." See Wilde, Crawshaw, and Sheldon, 1531.

8 In Spanish, the director described his early inspiration for the film in these words: "Empezó cuando tenía 6 años. Yo era un chiquillo y los domingos pasaban películas de terror en la televisión. Y vi La mujer y el monstruo a los seis años... y me enamoré de Julie Adams, pero me enamoré del amor que sentía la criatura por ella. Es decir, había una fascinación, que me conmovió muchísimo; de niño pensé ojalá y acaben juntos, pero no acabaron juntos, entonces me ha llevado cuarenta años corregir ese error cinematográfico" (Hernández Luján). For more on the director's early obsession with Creature from the Black Lagoon, see Borys Kit.

9 Two commentaries consulted suggest that Elisa's true nature never was human but amphibian, and thus at the end of the film the Creature restores her to her true being (Wilde et al., 1530; Siegel, 4, 6).

10 Most representative of the proposition that the three films form a trilogy is the article by Beatriz Martínez. There she writes, "Muchos consideran que La forma del agua supone el broche final a la trilogía que inició con El espinazo del diablo (2001) y que continuó con El laberinto del fauno (2006). Todas ellas estaban protagonizadas por personajes indefensos, puros de corazón que se encontraban inmersos en un panorama de inestabilidad política, cerrazón ideológica y degradación moral. Eran películas que se insertaban en el terreno de la fábula, pero en realidad se convertían como por arte de magia en potentes metáforas en torno al mal incrustado en nuestra sociedad. Había fantasmas y criaturas ancestrales, pero lo que daba más miedo eran las personas reales que ejercían su voluntad a la fuerza, a golpe de una dictatorial intransigencia."

11 The clearly non-human creatures of both Laberinto and Shape are of a different order from the ghost of the boy Santi in El espinazo del diablo. Santi is a dead 
human being, but the creatures of the other films are distinctly not human, even if they may have or acquire some human qualities and skills. Also, in the two more recent films, del Toro creates elaborate settings to depict places which, regardless of whether or not they simply exist in the protagonists' dream (Shape) or fantasy world (Laberinto), do exist on the screen in a visually compelling way for the viewer. There is nothing similar to these make-believe sets in Espinazo.

12 Whether or not the two resurrections are literal or imagined is immaterial here. Narratively, the deaths of both female protagonists are followed by the depiction of a resurrection, with which each film comes to an end.

13 Del Toro himself was, and is, upper-class, blond, and male. He has claimed it was his accent in English that gave him away and invited discriminatory treatment at the border.

\section{Works Cited}

Arnold, Jack, director. Creature from the Black Lagoon. Universal Pictures, 1954.

Belinchón, Gregorio. "Mis queridos monstruos." El País, Madrid, 10 Feb. 2018. elpais. com/cultura/2018/02/09/actualidad/1518183534_818852.html.

Brooke, James. "Pollution of Water Tied to Oil in Ecuador." New York Times, 22 March 1994. nytimes/1994/03/22/...pollution-of-water-tied-to-oil-in-ecuador.html.

Butler, Rhett. "Oil Extraction: How Oil Production Impacts the Rainforest." Amazon Watch, 7 Jan. 2013. amazonwatch.org/news/2013/0107-oil-extraction-how-oilproduction-impacts-the-rainforest.

del Toro, Guillermo, director. The Shape of Water. Fox Searchlight Pictures, 2017.

-. El Labertino del Fauno. Wild Bunch, Telecinco, Estudios Picasso, Tequila Gang, Esperanto Filmoj, Sententia Entertainment, 2006.

de la Cruz, Sor Juana Inés. "Respuesta a Sor Filotea de la Cruz." Obras completas, Porrúa Editorial, 1977, pp. 827-48.

Dillinger, Teresa L., et al. "Food of the Gods: Cure for Humanity? A Cultural History of the Medicinal and Ritual Use of Chocolate." The Journal of Nutrition, vol. 130, no. 8, Aug. 2000, pp. 2057S-2072S. www.academic.oup.com/jn/articleabstract/130/8/20576/4686320.

Finer, M., et al. "Oil and Gas Projects in the Western Amazon: Threats to Wilderness, Biodiversity, and Indigenous Peoples." 2008. PLoS, vol. 3, no. 8: e2932. doi.org/10.1371/journal.pone.0002932. 
"Goofs from The Shape of Water." Atom Tickets. www.atomtickets.com/movies/theshape-of-water/241090/goofs.

“Guillermo del Toro.” Wikipedia. www.en.wikipedia.org/wiki/Guillermo_del_Toro.

Hernández Luján, Raquel. "Crítica de La forma del agua, la película de Guillermo del Toro." HobbyConsolas, 5 March 2018. www.hobbyconsolas.com/reviews/criticaforma-agua-pelicula-que-guillermo-toro-inaugura-sitges-2017-168390.

Keegan, Rebecca. "How Guillermo del Toro Crafted the Perfect Monster-Romance for the Trump Era: In the Cold war-set The Shape of Water, the Mexican director takes aim at the desire to "Make America Great Again." Vanity Fair, 4 Sept. 2017. www. vanityfair.com/hollywood/2017/09/guillermo-del-toro-shape-of-water.

Kit, Borys. “How Guillermo del Toro's ‘Black Lagoon' Fantasy Inspired 'Shape of Water," The Hollywood Reporter, 3 Nov. 2017. www. hollywoodreporter.com/news/ how-guillermo-del-toros-black-lagoon-fantasy-inspired-shape-water-1053206.

Martínez, Beatriz. "Guillermo del Toro: 'Me dan miedo los seres humanos que creen tener la certeza absoluta.' " El País, 15 Feb. 2018. elpaís.com/elpaís/2018/02/13/ tentaciones/1518525954_468740lhtml.

Miller, Andrew E. "Oil in the Peruvian Amazon: A 2015 Panorama." Amazon Watch, 6 February, 2015. amazonwatch.org/news/2015/0206-oil-in-the-peruvian-amazon-a2015-pano.

Nicolini, Kim. "Surf N Turf: Love and Acceptance in Guillermo del Toro's The Shape of Water." 5 Jan. 2018, www.counnterpunch.org.

Rottenberg, Josh. "Guillermo del Toro's highly personal monster film The Shape of Water speaks to "what I feel as an immigrant," Los Angeles Times, 5 Sept. 2017. www.latimes.com/entertainment/movies/la-et-mn-guillermo-del-toro-telluride20170905-htmlstory.html.

Sample, lan. "Amazon rainforest threatened by new wave of oil and gas exploration." The Guardian, U.S. edition, 12 Aug. 2008. www.theguardian.com/ environment/2008/aug/13/conservation.forests.

Siegel,, Ben. "In Defense of Dagon: Intertextuality in The Shape of Water." Academia.edu. n.d. www.academia.edu/36241084/.

“The Shape of Water (2017): Goofs," IMDb. www.imdb.com/title/tt5580390/goofs. 
Walker, Hunter. "Donald Trump just released an epic statement raging against Mexican immigrants and 'disease."” Business Insider, 6 July 2015. www. businessinsider.com/donald-trumps-epic-statement-on-mexico-20157\#ixzz3fF897ElH.

Wilde, Alison, Gill Crawshaw, and Alison Sheldon. "Talking about The Shape of Water: three women dip their toes in." Disability \& Society, vol. 33, no. 9, 2018, pp. 152832. 